\title{
Phonological Development of an Arabic-English Bilingual Child during the One-word Stage
}

\author{
Hana A. Daana \\ Princess Alia University College, Al-Balqa Applied University, Jordan
}

Copyright $\bigcirc 2017$ by authors, all rights reserved. Authors agree that this article remains permanently open access under the terms of the Creative Commons Attribution License 4.0 International License

\begin{abstract}
The main purpose of this article is to provide a description of the phonological development in the speech of an Arabic-English bilingual child during the meaningful one-word production stage that is from 7 to 20 months of age. Data presented here are the result of recording sessions of spontaneous and non-spontaneous speech between the child and the author. The record, thus, is representative of the sounds which were produced in a meaningful verbal context. To the author's best knowledge, data on the phonological development of an Arabic-English bilingual child has not been published before. Therefore, this report may be of interest and value to researchers in the field of child language acquisition in general and bilingual first language acquisition in particular.
\end{abstract}

Keywords Phonological Development, Bilingual, Arabic, English

\section{Introduction}

A number of studies in child language acquisition have focused on the acquisition of phonology (Leopold [1] 1947; Jakobson [2] 1941/1968; Templin [3] 1957; Menn [4] 1971; Smith [5] 1973; Ingram [6,7] 1974/1979; Carter [8] 1975; Ferguson and Farwell [9] 1975; Kiparsky and Menn [10] 1977; Gusmann [11] 1980; Macken and Barton [12] 1980; Menn [13,14] 1980/1983; Schwartz and Leonard [15] 1982; MacKain [16] 1982; Atlinson [17] 1982; Ingram [18-20] 1985/ 1988/ 1990; Pye, Ingram and List [21] 1987; Ratner [22] 1994; Lleo and Prinz [23] 1996; Levelt, Schiller and Levelt [24] 2000; Keshavarz and Ingram [25] 2002; Stites, Demuth and Kirk [26] 2003; Pater and Barlow [27] 2003; Kirk and Demuth [28] 2005). This is because one of the most observable characteristics of child language acquisition is phonological development which is an obvious aspect of speech. Child-language acquisition in different languages of the world is of great importance as seen above. However, few case studies have reported on the acquisition of Arabic (Omar [29] 1973; Badri [30] 1983; Al-Amayreh [31] 1994;
Daana [32] 2009; Salim and Mehawesh [33] 2014). None of these studies have dealt with the early phonological development during the meaningful first-word stage. In addition, none of them have traced the development of English and Arabic sounds in the speech of a bilingual child.

As far as the early phonological development in the speech of a bilingual child is concerned, Keshavarz and Ingram [25] (2002) investigated the early development of the phonology of Farsi and English in the speech of Keshavarz' son applying the 'opposition theory' suggested by Jakobson [2] (1968 and cited in Ingram [34] 1996). In their study, they concluded that bilingual children are exposed to a larger sound inventory in their input as compared to monolingual children. Therefore, they have a larger sound inventory of phonemes in their speech. They also found out that the development of the phonological systems in the bilingual child's grammar corresponds to Jakobson's Opposition Theory. However, their study suffers from a particular drawback in regard to the handling of data. When they presented their data, they did not differentiate between English data and Farsi data. They illustrated their points in tables of mixed examples from English and Farsi. Moreover, since the study investigated meaningful production of sounds, they did not provide their readers with the glossary of his child's utterances especially the Farsi ones. The researcher of the present study decided to replicate Kesharvarz and Ingram's study [25] (2002) investigating the early development of the phonological systems of English and Arabic by a bilingual child.

The present study concentrates exclusively on speech sounds produced by the subject in the central phase of the development of sound system as Elliot [35] explained (1989). In other words, speech sounds produced in meaningful verbal contexts are the target sounds of this study. Pre-speech sounds and vocalizations are excluded from consideration. This is because most scholars agree that such sounds which are produced by children at the pre-linguistic stage of language development cannot be considered early language. The child's pre-linguistic sounds are involuntary responses controlled by a variety of stimuli such as pain, anger, hunger, discomfort, and the need to be cuddled. 
Brown [36] (2000) attested that during the pre-linguistic stage, the noises produced by all infants are universal in that they sound nearly the same in all languages. Ingram [34] (1996) cited Jakobson who said that the child possesses sounds which are common to all languages during the babbling or the pre-linguistic stage. Carter [8] (1975), Clark and Clark [39] (1977), Stark [38] (1980), Oller [39] (1980), and Brown [36] (2000) stated that children are born with the ability to produce and comprehend speech. This ability helped children produce these universal sounds. It is at a later stage that the phonemes in the child's mother tongue appear and those which do not exist in the child's mother tongue disappear. This later stage is defined by Clark and Clark [37] as the first-word stage (1977).

Hence, the one-word production period (7 to 20 months) was selected to study the language development of the subject of this study. According to Cruttenden [40] (1979), using sounds contrastively for the first time is a turning point in the process of acquiring a language. The study is limited to the contrastive use of English and Arabic sounds consonants and vowels - which was investigated and illustrated by examples.

\section{Jakobson's Theory of Opposition}

It is well attested in the literature that new born children slowly and gradually as well as systematically acquire their phonological system. Most of the references mentioned above and many more have approached this systematic process through different interpretations and hypotheses. One of these approaches is Jakobson's theory of opposition. Many scholars consider Jakobson's notion the most representative and explanatory theory to account for early phonological development. This theory of opposition assumes that children acquire new sounds according to their degree of contrast to other sounds (Cruttenden [40] 1979; Ingram [19] 1988). Ingram [36] (1996) considered Jakobson's theory to be the major theory as far as the acquisition of the phonological system is concerned. Jakobson [3] (1968) stated that sound distinctions and their relation to each other are more important than single sounds within the phonological system of any language. This leads to the assumption of the existence of a relatively identical order of acquiring the phonological system of any language. The speed of acquiring the phonological system of languages may differ amongst children; however, the order in which children acquire their different sound systems is almost the same all over the world.

Jakobson's theory is mainly concerned with speech production. He analyzed sets of data in published studies on the acquisition of 15 different languages. Most of the data he scrutinized was from languages such as Czech, Bulgarian, Russian, Polish, and Serbo-Croatian. The theory proposes the existence of linguistic laws which influence the child's linguistic system. It further adds that the role of such linguistic laws is to control the order of acquiring oppositions. He further elaborated that the child's early words are not only restricted by the child's articulatory constraints, they are also restricted by the underlying linguistic system. Jakobson believes that the stage in which the child starts acquiring oppositions is the first and crucial stage upon which further development is based. Throughout this first stage, the child develops the minimal consonant and vowel system. Table 1 , borrowed from Ingram [34] (1996, p. 192) illustrates Jakobson's proposed order of acquiring oppositions.

Hence, the stage at which the child starts using the sounds contrastively is considered the threshold of the process of the child acquiring the phonological system of his/her native language (Cruttenden [40] 1979). It is only at this stage that the child starts using the language meaningfully.

Table 1. The First Stage of Phonological Development

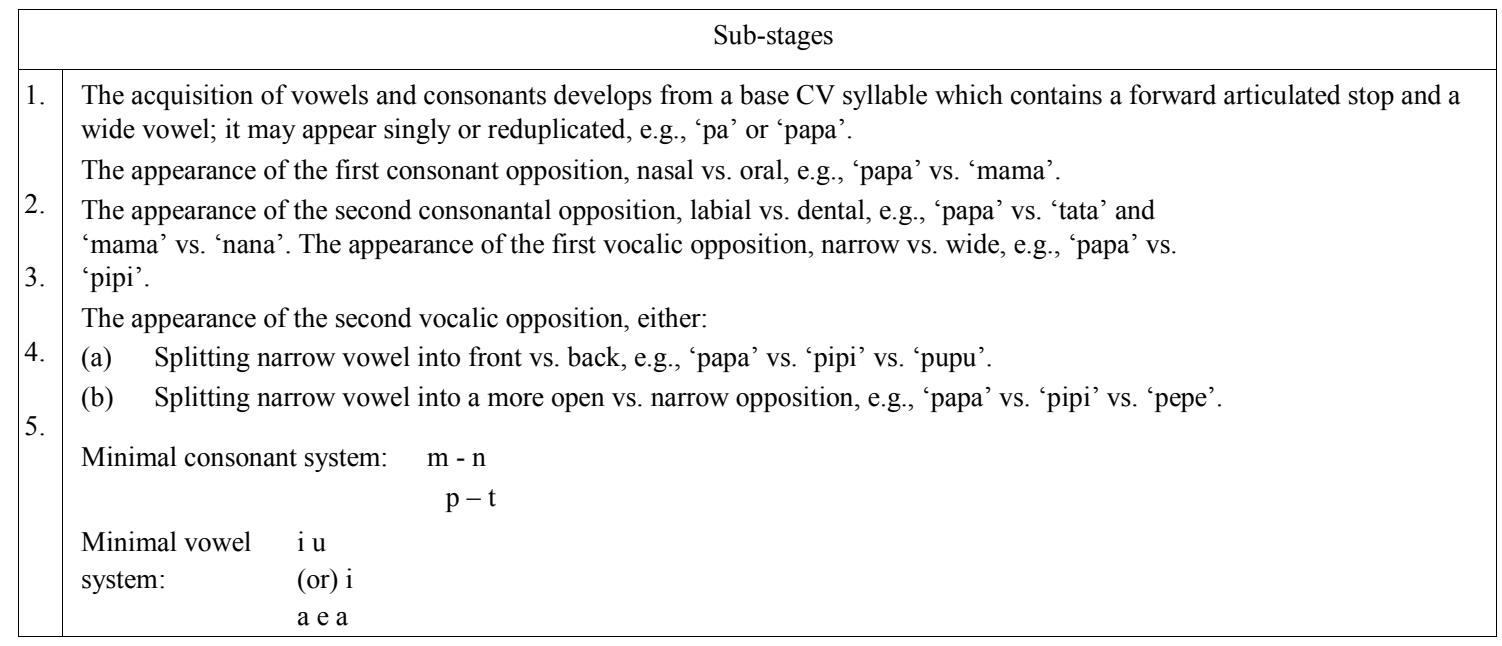




\section{Method}

\subsection{Subject}

The subject of the present study was the author's only child, Yanal. Yanal was born in the United Kingdom where his mother was working on her $\mathrm{PhD}$ research in Language Acquisition. Since the author's child had the chance of being a simultaneous bilingual by virtue of the fact that he was exposed to two languages for the first five years of his life, the author made sure that the child was exposed to the form of Arabic spoken in the capital city of Jordan (Ammani Arabic) and the form of English used at that geographical place in England.

\subsection{The Strategy of the Input}

No particular bilingual policy was established. Yanal was sent to the university day-care nursery when he was 5 months old. He used to spend three days a week from 8:00 until 3:30. Then he was sent to a nursery close to his residency on a daily basis from 8:00 until 3:30; therefore, he was exposed to English during this time. The remaining time of the day and during the weekends, Yanal was spoken to in Arabic by his father and mostly in English but occasionally in Arabic by his mother. As both parents were fluent in English and Arabic, they spoke to each other in English and Arabic in the presence of the child. Up to the age of five, Yanal was exposed to English through national TV channels, English-speaking family friends, and his friends in the nursery and kindergarten in addition to his mother.

As far as Yanal's exposure to Ammani Arabic is concerned, he was exposed to Ammani Arabic through his father and occasionally his mother. The subject was also exposed to Jordanian Arabic through a very few Arabic-speaking families who happened to be there with their children. Those Arabic-speaking families occasionally visited the family or infrequently went out together on the weekends and holidays. However, when Yanal became 4, the children of those families and Yanal started to communicate in English most of the time.

Based on what has been said, and by virtue of the fact that there was no one-parent one-language strategy, the subject would use English more than Arabic. Although he could comprehend everything said to him in Arabic, his preferable language for his responses was English unless he was asked to respond in Arabic. To overcome such a drawback, the researcher tried to reduplicate the data-elicitation sessions in terms of language, purpose, and time.

\subsection{Data Collection}

Data were collected in the first five years of Yanal's life and in the form of audio-recordings and informal experimental conversational sessions. The phonetic transcriptions of Yanal's utterances in the two languages were included in a diary on site by the researcher who is a trained phonetician. Also, details of the context in which such utterances were produced as well as some gestures, body language, and facial expressions were added. All sessions were audio-recorded using a Panasonic RX-M70M3 device. The audio-recorded material, which was kept chronologically, was transcribed subsequently by the researcher and was double checked by the author's Jordanian colleague who happened to be working on his $\mathrm{PhD}$ research in phonology at the time.

Yanal's comprehension was occasionally checked even though this study is mainly concerned with the child's production. In the early stages, Yanal's comprehension was tested by telling him the names of different toys and then asking him to bring them, e.g., "Yanal, bring me the car." The researcher also named different pictures from his books and asked him to point to them, e.g., "Yanal, where is the tiger?" In most cases, he responded appropriately. The researcher conducted the same experiment with the same theme and the same tool twice, in English and then in Arabic.

The main aim of this study is the contrastive use of phonemes, so non-contrastive or meaningless sounds produced were ignored. Also, for the purpose of this study, the researcher started analyzing Yanal's production when his first comprehensible words were produced ( 7 months on). Yanal's transcribed utterances were classified by language and age. For example, A-10 indicates Arabic utterances produced at the age of 10 months. Following Keshavarz and Ingram [25] (2002) method of representing age, the child's age is represented by months rather than by weeks and/or days. Data were saved in computer files. Each file included the transcription of Yanal's utterance, the transcription of the adult-equivalent, the word in orthography, number of times the utterance was repeated, and other details about the context if needed. A glossary of the Arabic words was also given for the Arabic data.

As mentioned earlier, the subject's sounds that were used to construct meaningful words during the first stage were identified by entering them into computer files using broad Charis SIL IPA fonts. Only the data collected between the ages of 7 to 20 months were analyzed for the purpose of this study. In other words, it was at the age of 7 months that he produced his first meaningful word while at the age of 20 months, he started producing a few two-word utterances.

\section{Comparison between English and Arabic}

\subsection{Sound Systems}

Arabic is a member of the Semitic languages. It is the official language in Jordan. The dialect acquired by the child in the present study is the one spoken in the capital Amman, which is the native variety of the child's mother and father.

Because English and Arabic belong to two different families of language, they differ in their phonological structures (Daana [32] 2009). Apart from phonetic 
differences, there are certain English consonants and vowels which do not exist in the Arabic dialect investigated in this study. These include /ð, $\theta, \mathrm{y}, \mathrm{t}$, d $, \mathrm{v}, \Lambda, \mathrm{J}$, and $ә /$. The English low front short $/ \downarrow /$ is symbolized as $/ a /$ throughout this study as it corresponds to the Arabic low front short /a/. All English diphthongs do not exist in Arabic. Similarly, some of the Arabic consonants and vowels are lacking in English. These include:

/t / dental emphatic voiceless stop

/di/ dental emphatic voiced stop

/P/ glottal voiced stop

/ș/ alveolar emphatic voiceless fricative

$/ \chi /$ uvular voiceless fricative

$/ \gamma /$ uvular voiced fricative

$/ \mathrm{h} /$ pharyngeal voiceless fricative

/ $/$ pharyngeal voiced fricative

/e/ mid-low front long vowel

/a/ low front short vowel

/a/ low front long vowel

\subsection{Syllable Structure}

English has a wider range of clusters than Ammani Arabic. Keshavarz [42] (1997, pp. 44-47) lists 18 types of syllables for English. The syllable structure in English can be represented as $(\mathrm{C})(\mathrm{C})(\mathrm{C}) \mathrm{V}(\mathrm{C})(\mathrm{C})(\mathrm{C})(\mathrm{C})$ whereas in Ammani Arabic only 9 syllable types exist. The syllable types in Ammani Arabic can be represented as $(\mathrm{C})(\mathrm{C}) \mathrm{CV}(\mathrm{C})(\mathrm{C})$. As can be seen, Arabic permits three consonant clusters in the syllable initial position, and it allows clusters of two consonants in the syllable final position. English, on the other hand, permits up to three consonants initially and up to four word-finally. The significant contrast between English and Arabic in regard to syllable structure is that English permits onsetless syllables while Arabic does not.

\section{Data Analysis}

\subsection{Consonantal System}

Most of Yanal's first English and Arabic words were of a CV structure (table 2).

Table 2. Yanal's CV English and Arabic Words

\begin{tabular}{|c|c|c|c|}
\hline Language & Yanal's Production & Adult Form & Glossary \\
\hline \multirow{13}{*}{ English } & [bo:] & /bu:ts/ & boots \\
\hline & {$[\mathrm{tu}:]$} & $/ \mathrm{tu}: /$ & two \\
\hline & [?i:] & /Ori:/ & three \\
\hline & [ba] & $/ \mathrm{b}_{\Lambda \mathrm{S}} /$ & bus \\
\hline & {$[\mathrm{ka}]$} & /kat/ & cat \\
\hline & [ka:] [kar] & /skai/ & sky \\
\hline & [ki:] & /ki:/ & key \\
\hline & [po:] & /spu:n/ & spoon \\
\hline & [na:] [no] & /nəuz/ & nose \\
\hline & [nəo] & /nəo/ & no \\
\hline & [su:] [Ju:] & /dzu:s/ & juice \\
\hline & [fi:] & /fi:t/ & feet \\
\hline & [fi:] & $/$ tofi/ & toffee \\
\hline \multirow{10}{*}{ Arabic } & [bo:] & /bo:t/ & boots \\
\hline & [ma:] & $/ \mathrm{maj} /$ & water \\
\hline & [na:] & /na:m/ & slept ( $3^{\text {rd }}$ person singular $)$ \\
\hline & [na:] & /jana:1/ & Yanal \\
\hline & [fa] & /fawa:z/ & Fawaz (proper name) \\
\hline & [fo:] & /Sașfu:r/ & bird \\
\hline & {$[\chi \mathrm{a}]$} & /хa:jef/ & I am afraid \\
\hline & [ko:] & /ko:1/ & eat \\
\hline & [ju:] & / $\mathrm{ju}: /$ & what \\
\hline & {$[\mathrm{su}:]$} & / fu:f/ & look \\
\hline
\end{tabular}


Yanal's first words also included reduplication of an open syllable consisting of a consonant plus a vowel (table 3).

Table 3. English and Arabic Words with Reduplication

\begin{tabular}{|c|c|c|c|}
\hline Language & Yanal's Production & Adult Form & Glossary \\
\hline \multirow{7}{*}{ English } & [bebe] & /berbi/ & baby \\
\hline & [kaka] & /kerk/ & cake \\
\hline & [nunv] & /nәш/ & no \\
\hline & [baba] & /bıs/ & bus \\
\hline & $[\mathrm{m}\lrcorner \mathrm{m}\lrcorner]$ & /momi/ & mommy \\
\hline & [рара] & /рәра:/ & daddy \\
\hline & [baba] & /bai/ & bye \\
\hline \multirow{9}{*}{ Arabic } & [mama] & /mama/ & mommy \\
\hline & [țața] & /bațața/ & potatoes \\
\hline & [da:da:] & /da:d $\varepsilon /$ & childish word to encourage the child to walk \\
\hline & {$[\mathrm{mem \varepsilon}]$} & /laћme/ & meat \\
\hline & [tata] & /te:ta/ & grandmother \\
\hline & [nenc] & /PaSți:ni:/ & give me \\
\hline & [baba] & /bai/ & bye \\
\hline & [baba] & /ba:ș/ & bus \\
\hline & [fafa:] & /fawa:z/ & proper name \\
\hline
\end{tabular}

Later, closed syllables were produced without reduplicated syllables (table 4).

Table 4. Yanal's English and Arabic Closed Syllabic Words

\begin{tabular}{|c|c|c|c|}
\hline Language & Yanal's Production & Adult Form & Glossary \\
\hline English & {$\left[\int \varepsilon s\right]\left[\int \mathrm{IS}\right]$} & /tyips/ & chips \\
\hline \multirow[t]{23}{*}{ 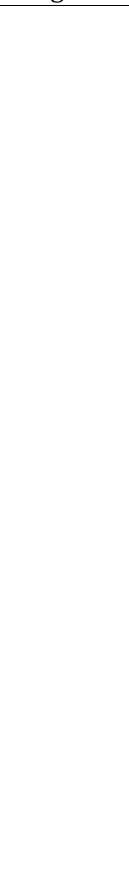 } & [kat] & /kat/ & cat \\
\hline & [fain] [fav] & /faiv/ & five \\
\hline & [eIt] & /eit/ & eight \\
\hline & [as] & /ho:s/ & horse \\
\hline & [bak] & /bark/ & bike \\
\hline & {$[\mathrm{b} \Lambda \mathrm{s}]$} & /bns/ & bus \\
\hline & [at] [hat] & /hat/ & hat \\
\hline & [bok] & /buk/ & book \\
\hline & [fit] & $/ \mathrm{fr} / /$ & fish \\
\hline & {$[\varepsilon g k][\varepsilon g]$} & /عg/ & egg \\
\hline & [po:k] [pu:n] & /spu:n/ & spoon \\
\hline & [b3:d] & /bs:d/ & bird \\
\hline & [betct] & /rabit/ & rabbit \\
\hline & [sots][sos] & /soks/ & socks \\
\hline & {$[\Lambda \mathrm{p}]$} & $/ \Lambda \mathrm{p} /$ & up \\
\hline & {$[\Lambda \mathrm{n}]$} & /wan/ & one \\
\hline & [fi:] & /Ori:/ & three \\
\hline & [den] & /scvn/ & seven \\
\hline & {$[\mathrm{n} \varepsilon n][\mathrm{t} \varepsilon n]$} & $/ \mathrm{ten} /$ & ten \\
\hline & [eIt] & /eit/ & eight \\
\hline & [nan] & /nain/ & nine \\
\hline & [sits] & /sıks/ & six \\
\hline & [hed] & /hed/ & head \\
\hline \multirow[t]{10}{*}{ Arabic } & {$[\mathrm{k} \varepsilon \chi][\mathrm{kI} \chi]$} & $/ \mathrm{kI} \chi /$ & dirty childish word) \\
\hline & [ma:m] [na:m] & /nam/ & sleep \\
\hline & [ba:b] & /ba:b/ & door \\
\hline & [ba:s] & /ba:ș/ & bus \\
\hline & {$[\mathrm{mam}][\mathrm{men}]$} & /maj/ & water \\
\hline & [?aff] & /Paraf/ & disgusting \\
\hline & [ba:t] & /kta:b/ & book \\
\hline & [xaff] & /2axa:f/ & I am afraid \\
\hline & [kak] & /kalb/ & dog \\
\hline & [ba:k] & /Subba:k/ & window \\
\hline
\end{tabular}


The first consonantal phonetic contrasts Yanal developed were as follows:

1. Opposition between nasal and oral consonants, e.g. [baba], [papa], and [mama] / [țața] and [mama] / [kaka] and [mama] / [ka] and [ na ].

2. Opposition between bilabial and alveolar consonants, e.g. [meme] and [nenc] / [mama] and [tata] / [tata] and [ papa], [baba ].

3. The data also contained opposition between velar and bilabial consonants,

e.g. [kaka] and [ mama], [papa], [baba ].

4. A fourth type of opposition was found between labiodental fricative and bilabial consonants, e.g., [fafa:], [mama], [papa], [baba].

5. Velar and labiodentals fricative consonants can be said to have been used contrastively as opposition, e.g., [kaka], [fafa:].

The most frequent consonants the subject produced during phase 1 were bilabial, alveolar and velar oral and nasal stops.
These included: [p, b, d, t, t, m, n, k]. [?] was used less frequently.

The first occurrence of a non-plosive consonant was the fricative sounds: $/ \int /$ which was used to replace the affricate in the word 'chips' and in the Arabic word / u u:f/ 'look' at the age of 11 months. /f/ was first used in his father's name at the age of 12 months. /s/ and sometimes / $/$ / replaced the affricate $/ \mathrm{d} /$ in the English word 'juice' at the same age. He produced his first $/ \chi /$ and $/ s$ / in the Arabic words [ $\chi$ a] for /Raxa:f/ 'I am scared' and [ba:s / for 'bus' respectively one month later. /h/ was first produced in the child's mother's name at the age of 14 months.

All in all, the subject produced 14 consonants during phase 1 (7-20 months). These are illustrated in table 5 .

It needs to be pointed out that the consonants $[\mathrm{v}, \mathrm{g}]$ occurred only once in the English words [fav] 'five' and [عg] 'egg' respectively. Since these sounds occurred only once and in light of Ingram's [34] criterion of frequency (1996), they could not be considered a part of Yanal's phonetic inventory at this stage.

Table 6 gives the frequency of occurrences of all English and Arabic consonants together with illustrative examples from the data.

Table 5. The Consonants Produced by the subject during Stage 1

\begin{tabular}{|c|c|c|c|c|c|c|}
\hline \multirow{2}{*}{ Manner of Articulation } & \multicolumn{5}{|c|}{ Place of Articulation } & Glottal \\
\cline { 2 - 7 } & Bilabial & Labio- dental & Alveolar & Alveo- palatal & Velar & k \\
\hline Stops & $\mathrm{P}, \mathrm{b}$ & & $\mathrm{t}, \mathrm{t}, \mathrm{d}$ & & $\chi$ & $\mathrm{h}$ \\
\hline Fricatives & & $\mathrm{f}$ & $\mathrm{s}$ & $\mathrm{f}$ & & \\
\hline Nasals & $\mathrm{m}$ & & $\mathrm{n}$ & & & \\
\hline
\end{tabular}

Table 6. The Frequency of Occurrence of English and Arabic consonants

\begin{tabular}{|c|c|c|c|}
\hline Consonants & Frequency & Language & Example \\
\hline$/ \mathrm{b} /$ & 23 & $\begin{array}{l}\text { English } \\
\text { Arabic }\end{array}$ & $\begin{array}{l}\text { [bo:] [bebe] [bak] } \\
\text { [bo:] [baba] [ba:b] }\end{array}$ \\
\hline$/ \mathrm{p} /$ & 6 & English & [po:] [papa] [pu:n] \\
\hline$/ \mathrm{t} /$ & 15 & $\begin{array}{l}\text { English } \\
\text { Arabic }\end{array}$ & $\begin{array}{c}\text { [tu:] [bstct][ert] } \\
\text { [tata] [ba:t] }\end{array}$ \\
\hline$/ \mathrm{t} /$ & 3 & Arabic & [țața] \\
\hline$/ \mathrm{d} /$ & 3 & $\begin{array}{l}\text { English } \\
\text { Arabic }\end{array}$ & $\begin{array}{c}{[\mathrm{d} \varepsilon n]} \\
{[\mathrm{da}: \mathrm{d} \varepsilon]}\end{array}$ \\
\hline$/ \mathrm{k} /$ & 13 & $\begin{array}{l}\text { English } \\
\text { Arabic }\end{array}$ & $\begin{array}{c}{[\mathrm{ka}][\mathrm{kaka}][\mathrm{kat}]} \\
{[\mathrm{ko:}][\mathrm{kak}]}\end{array}$ \\
\hline /P/ & 9 & $\begin{array}{l}\text { English } \\
\text { Arabic }\end{array}$ & [?i:] [?aff] [Pana] \\
\hline$/ \mathrm{m} /$ & 17 & $\begin{array}{l}\text { English } \\
\text { Arabic }\end{array}$ & $\begin{array}{c}{[\mathrm{mama}]} \\
{[\mathrm{ma}:][\mathrm{m} \varepsilon \mathrm{m} \varepsilon][\mathrm{ma}: \mathrm{m}]}\end{array}$ \\
\hline$/ \mathrm{n} /$ & 29 & $\begin{array}{l}\text { English } \\
\text { Arabic }\end{array}$ & $\begin{array}{c}\text { [na] [nonv] [nen] } \\
\text { [na:] [nধne] [na:m] }\end{array}$ \\
\hline$/ \mathrm{s} /$ & 5 & English & 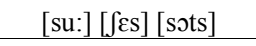 \\
\hline $\mid \mathrm{g} /$ & 4 & $\begin{array}{l}\text { English } \\
\text { Arabic }\end{array}$ & {$\left[\int \varepsilon s\right]\left[\int u:\right]$} \\
\hline$|\chi|$ & 3 & Arabic & {$[\mathrm{k} \varepsilon \chi]\left[\mathrm{k} \_\chi\right]$} \\
\hline$/ \mathrm{h} /$ & 4 & English & [hat] [hed] \\
\hline /f/ & 5 & $\begin{array}{l}\text { English } \\
\text { Arabic }\end{array}$ & $\begin{array}{l}\text { [fi:] [farn] [fav] } \\
\text { [fa] [fafa] [?aff] }\end{array}$ \\
\hline
\end{tabular}


As can be seen, the most frequent consonants were the front stops $/ \mathrm{b} /$ and $/ \mathrm{t} /$, as well as the nasals $/ \mathrm{m} / \mathrm{and} / \mathrm{n} /$. This has also been shown in other related studies in the literature (Vihman [43] 1996; Adnyani and Pastika [44] 2016).

\subsubsection{Variation in the Position of the Consonants}

It has been attested that consonants are generally learnt first in syllable-initial position, then word-medial position, and lastly in syllable-final position (Cruttenden [40] 1979). Olmsted [45] (1971) and Ferguson and Farwell [9] (1975) provided one exception when they found that fricatives are used first in the post-vocalic position only. Yanal's phonetic inventory was illustrated separately for word-initial consonants (table 7), word-medial consonants (table 8), and word-final consonants (table 9).

Table 7. Word-Initial Consonants

\begin{tabular}{|c|c|}
\hline \multicolumn{2}{|r|}{ Word-Initial Consonants } \\
\hline \multicolumn{2}{|r|}{ English } \\
\hline$/ \mathrm{b} /$ & [bo:] [ba] [bebe] [baba] [bak] [bok] [bs:d] [betct] \\
\hline$/ \mathrm{p} /$ & [ps:] [papa] [pэ:k] [pu:n] \\
\hline$/ \mathrm{t} /$ & {$[\mathrm{tu}:][\mathrm{ten}]$} \\
\hline$/ \mathrm{k} /$ & [ka] [kaka] [kat] \\
\hline$/ \mathrm{d} /$ & [den] \\
\hline$/ \mathrm{n} /$ & [na] [nono] [nen] [nan] \\
\hline$/ \mathrm{m} /$ & [mama] \\
\hline$/ \mathrm{P} /$ & [?i:] \\
\hline$/ \mathrm{d} /$ & 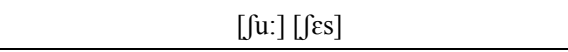 \\
\hline$/ \mathrm{s} /$ & [su:] [sots][sos] [sits] \\
\hline$/ \mathrm{f} /$ & [fi:] [fain] [fav] [fit] \\
\hline$/ \mathrm{h} /$ & [hat] [hed] \\
\hline \multicolumn{2}{|r|}{ Arabic } \\
\hline$/ \mathrm{b} /$ & [bo:] [baba] [ba:t] [ba:b] [ba:s] [ba:k] \\
\hline$/ \mathrm{d} /$ & {$[\mathrm{dad} \varepsilon]$} \\
\hline$/ \mathrm{t} /$ & [tata] \\
\hline$/ \mathrm{t} /$ & [țața] \\
\hline$/ \mathrm{S} /$ & [?aff] \\
\hline$/ \mathrm{k} /$ & {$[\mathrm{ko}:][\mathrm{k} \varepsilon \chi][\mathrm{kr} \chi][\mathrm{kak}]$} \\
\hline$/ \mathrm{m} /$ & [ma:] [mama] [meme] [ma:m] [mam] [men] \\
\hline$/ \mathrm{n} /$ & [na:] [nenc] [na:m] \\
\hline $\mid \mathrm{J} /$ & / fu:/ \\
\hline$/ \mathrm{f} /$ & [fo:][fa:] [fafa] \\
\hline$|\chi|$ & {$[\chi \mathrm{a}][\chi \mathrm{aff}]$} \\
\hline
\end{tabular}


Table 8. Word-Medial Consonants

\begin{tabular}{|c|c|}
\hline \multicolumn{2}{|c|}{ Word-Medial Consonants } \\
\hline \multicolumn{2}{|c|}{ English } \\
\hline$/ \mathrm{b} /$ & [bebe] [baba] [baba] \\
\hline$/ \mathrm{p} /$ & [papa] \\
\hline$/ \mathrm{t} /$ & {$[\mathrm{bet} t \mathrm{t}]$} \\
\hline$/ \mathrm{k} /$ & [kaka] \\
\hline$/ \mathrm{n} /$ & {$[\mathrm{nonv}]$} \\
\hline$/ \mathrm{m} /$ & [mama] \\
\hline \multicolumn{2}{|c|}{ Arabic } \\
\hline$/ \mathrm{b} /$ & [baba] \\
\hline$/ \mathrm{d} /$ & {$[\mathrm{dad} \varepsilon]$} \\
\hline$/ \mathrm{t} /$ & [țața] \\
\hline$/ \mathrm{t} /$ & [țața] \\
\hline$/ \mathrm{m} /$ & {$[\mathrm{mama}][\mathrm{m} \varepsilon \mathrm{m} \varepsilon]$} \\
\hline$/ \mathrm{n} /$ & {$[\mathrm{n} \varepsilon \mathrm{n} \varepsilon]$} \\
\hline$/ \mathrm{f} /$ & [fafa] \\
\hline
\end{tabular}

Table 9. Word-Final Consonants

\begin{tabular}{|c|c|}
\hline \multicolumn{2}{|r|}{ Word-Final Consonants } \\
\hline \multicolumn{2}{|r|}{ English } \\
\hline$/ \mathrm{t} /$ & [at][hat] [fit] [betct] [kat] [ert] \\
\hline$/ \mathrm{k} /$ & {$[\mathrm{bok}][\mathrm{po:k}][\mathrm{\varepsilon gk}][\mathrm{bak}]$} \\
\hline$/ \mathrm{d} /$ & {$[\mathrm{b} 3: \mathrm{d}][\mathrm{h} \varepsilon \mathrm{d}]$} \\
\hline$/ g /$ & {$[\varepsilon g]$} \\
\hline$/ \mathrm{n} /$ & {$[\Lambda \mathrm{n}][\mathrm{pu}: \mathrm{n}][\mathrm{n} \varepsilon \mathrm{n}][\mathrm{t} \varepsilon \mathrm{n}][\mathrm{d} \varepsilon \mathrm{n}][\mathrm{nan}][\mathrm{faIn}]$} \\
\hline$/ \mathrm{s} /$ & {$[\mathrm{sots}][\mathrm{sos}][\mathrm{as}][\mathrm{sits}]\left[\int \varepsilon \mathrm{s}\right]$} \\
\hline$/ \mathrm{v} /$ & {$[\mathrm{fav}]$} \\
\hline \multicolumn{2}{|r|}{ Arabic } \\
\hline$/ \mathrm{b} /$ & {$[\mathrm{ba}: \mathrm{b}]$} \\
\hline$/ \mathrm{t} /$ & [ba:t] \\
\hline$/ \mathrm{k} /$ & [ba:k] [kak] \\
\hline$/ \mathrm{m} /$ & {$[\mathrm{ma}: \mathrm{m}][\mathrm{na}: \mathrm{m}][\mathrm{mam}]$} \\
\hline$/ \mathrm{n} /$ & {$[\mathrm{men}]$} \\
\hline$/ \mathrm{f} /$ & 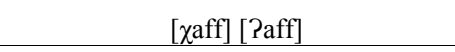 \\
\hline$|x|$ & {$[\mathrm{k} \varepsilon \chi][\mathrm{k} \iota]$} \\
\hline$/ \mathrm{s} /$ & [ba:ș] \\
\hline
\end{tabular}

The three tables above show that not only did stops occur in both initial and non-initial positions, but also fricatives. This is not in line with observations made by other researchers declaring that fricatives occur but only post-vocalic (Olmsted [45] 1971; Ferguson and Farwell [9] 1975; Cruttenden [40] 1979).

\subsection{Vowel System}

An opposition was also found between different types of vowels, e.g., [mama] vs. [mems]). The first vowel phonemes the subject produced were $/ \mathrm{a} /, / \mathrm{a} / \mathrm{,} / \varepsilon /, / \mathrm{u} / \mathrm{,}$ $/ \mathrm{u} /, / \mathrm{s} /, / \mathrm{s} /, / \mathrm{I} /, / \mathrm{i}: /, / \mathrm{a} /, / 3: /$, and $/ \Lambda /$. Most of the vowels used in Yanal's open syllables were long, such as [bo:], [su:], [fi:], and [ma:]. The only short vowel used in open non-reduplicated syllables was/a/ in [ba]. Other short vowels were used in reduplicated syllables, such as [nunv] and [meme]. Almost all the vowels used in Yanal's closed

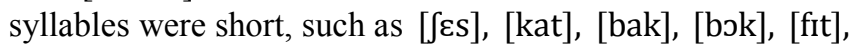
and $[\Lambda \mathrm{n}]$. Long vowels, such as [i:], [u:], [0:], [a:] and [3:], were less frequently used in closed syllables. The first three English diphthongs to appear at this stage were [aI], [eI], and [əu] in [faIn], [eIt], and [nəu] respectively. However, these diphthongs were only used in /farv/, /skai/, /eit/, and /nəv/ and not in any other words; therefore, they are going to be overlooked. During this single-word stage ( $7-20$ months), the subject produced 12 vowels and three diphthongs altogether.

It needs to be pointed out that the subject was able to distinguish between the English back vowel/a:/ and the Arabic front vowel/a:/ and he made use of them correctly.

$\mathrm{He}$ also made use of the English $/ \Lambda /, / \mathrm{J} /$, and /aI/ vowels although they do not exist in Arabic. Yanal, as a bilingual child, correctly uses two vowel systems of two different languages and has no problem differentiating between these systems. Table 10 gives the frequency of vowels with illustrative examples.

Table 10. Frequency of the Occurrences of English and Arabic Vowels

\begin{tabular}{|c|c|c|c|}
\hline Vowels & Frequency & Language & Example \\
\hline$/ \mathrm{a} /$ & 38 & $\begin{array}{l}\text { English } \\
\text { Arabic }\end{array}$ & $\begin{array}{c}\text { [bak] [papa] [na] [kaka] } \\
{[\mathrm{ka}][\mathrm{kat}][\mathrm{as}][\mathrm{hat}][\mathrm{at}]} \\
\text { [baba] [tata] [țața] [mama] }\end{array}$ \\
\hline /a:/ & 7 & $\begin{array}{l}\text { English } \\
\text { Arabic }\end{array}$ & $\begin{array}{c}{[\mathrm{ka}:][\mathrm{ka}: \mathrm{z}]} \\
{[\mathrm{ba}: \mathrm{b}][\mathrm{ba}: \mathrm{t}][\mathrm{ma}:][\mathrm{ma}: \mathrm{m}]}\end{array}$ \\
\hline /o:/ & 7 & $\begin{array}{l}\text { English } \\
\text { Arabic }\end{array}$ & $\begin{array}{c}\text { [po:][fo:][po:k] } \\
\text { [bo:] [ko:] }\end{array}$ \\
\hline$/ 0 /$ & 6 & English & {$[\mathrm{sots}][\mathrm{n} \supset][\mathrm{bok}]$} \\
\hline /i:/ & 6 & English & [?i:] [fi:] [fi:t] [ki:] \\
\hline$/ \mathrm{I} /$ & 4 & $\begin{array}{l}\text { English } \\
\text { Arabic }\end{array}$ & $\begin{array}{l}{\left[\int \mathrm{Is}\right][\mathrm{fit}][\mathrm{sits}]} \\
{[\mathrm{kr} \chi]}\end{array}$ \\
\hline /3:/ & 2 & English & [b3:d] \\
\hline$/ \varepsilon /$ & 8 & $\begin{array}{l}\text { English } \\
\text { Arabic }\end{array}$ & 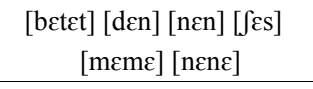 \\
\hline /u:/ & 5 & $\begin{array}{l}\text { English } \\
\text { Arabic }\end{array}$ & $\begin{array}{c}\text { [pu:n] [tu:] [su:] } \\
\text { [fu:] }\end{array}$ \\
\hline$/ \mathrm{v} /$ & 3 & English & {$[$ nonv] } \\
\hline$/ \alpha /$ & 3 & English & {$[\mathrm{b} \Lambda \mathrm{s}][\Lambda \mathrm{n}][\Lambda \mathrm{p}]$} \\
\hline
\end{tabular}

As can be seen in table 10, English/a/ and Arabic short /a/ were the first to appear and the most frequently used amongst the other vowels. Almost all of the Arabic vowels 
were used either word-medially or finally. None of them were used word-initially simply because Arabic does not allow onsetless syllables. On the other hand, English vowels were used in the three positions. It is important to point out that the subject deleted an initial and already existing consonant in English words in very few cases but never in Arabic. The English word 'hat' was produced as [at] several times. The word 'head' was produced as $[\varepsilon d]$ several times as well. Taking into consideration that English allows an onsetless syllable but Arabic does not, this exclusive deletion of English vowels in the initial position suggests that Yanal, being a bilingual child, is not only able to differentiate between the phonetics of both languages, he is also able to differentiate between the two phonological systems and produces the sounds accordingly.

\subsection{Syllable Structure}

Altogether four syllable types were found in Yanal's speech during this stage. Two of them were common to both languages (CV and CVC), one type was exclusive to English (VC) and one type was with a coda cluster which was produced only twice (CVCC) in one English word. VC was exclusive to English only because it does not exist in Arabic. CVCC was only used on two occasions [fi:ts]; therefore, this type receives no further analysis. This shows that a bilingual child can make use of the syllable structures of both languages correctly abiding by the phonological laws of each language. Table 11 below lists the different types of syllables produced by the subject during the first stage together with illustrative examples.

Table 11. Yanal's English and Arabic Syllable Structures

\begin{tabular}{|c|c|}
\hline Syllable Type & Examples \\
\hline $\mathrm{VC}$ & $/ \Lambda \mathrm{n} / / \mathrm{as} / / \mathrm{at} / / \varepsilon \mathrm{g} /$ \\
\hline $\mathrm{CV}$ & 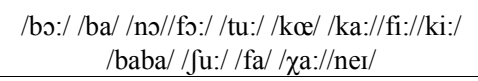 \\
\hline $\mathrm{CVC}$ & 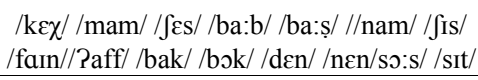 \\
\hline CVCC & /fi:ts/ \\
\hline
\end{tabular}

It is worth pointing out that the most frequently used syllable type is the $\mathrm{CV}$ type during the single-word production period. This confirms Jakobson's [2] (1968) proposed order of acquisition, reiterated by many other researchers (Ingram [34] 1996). According to Jakobson's theory, the CV syllable is considered the starting point in acquisition. This syllable may appear singly, e.g., [pa] and [ma] or in reduplicated forms, e.g., [papa] and [mama]. Ingram [34] (1996) further elaborated that all further development is based on this initial syllable. The next most frequent syllable type was CVC. Because the use of VC is exclusive to one language, it is expected to be less frequently used. The fact that the subject made use of CVCC in very few occasions suggests that he was not yet able to produce syllable types with clusters at this stage of acquisition.

\section{Conclusions}

In addition to being the first bilingual case study on the acquisition of Arabic and English phonological systems, the main contribution of this paper is to provide further evidence that children acquiring two first languages have a larger sound inventory compared to monolingual children. The findings of this research confirm Keshavarz and Ingram [25] (2002) findings. The bilingual subject in the present study was able to produce English consonants and vowels that do not exist in the Arabic that he was exposed to. These include $/ \partial, \theta, y, t, d, \Lambda, J$, and $ə /$. He was also able to make use of Arabic consonants and vowels that the English language lacks. These include/t, d, ?, s, $\chi, \gamma, \hbar$, , e:, and a/. This has given the subject access to a larger number of consonants and vowels resulting in enlarging his inventory of phonemes. As Keshavarz and Ingram[25] (2002) states, the literature shows that bilingual children are successful in making use of two systems in two different languages simultaneously. He also cited Watson's explanation that this successful use does not take the bilingual child more time than a monolingual child takes to acquire one language.

The findings in this case study also confirm Jakobson's theory of opposition and order of acquisition of sounds. As stated earlier, it has been shown in the literature that the CV syllable is the starting point in the acquisition for both vowels and consonants. Further development is said to be based on this initial syllable. The results of this study also show that $\mathrm{CV}$ is the first to appear and is the most frequently used one in the subject's data followed by CVC.

\section{REFERENCES}

[1] W. Leopold. Speech Development of a Bilingual Child: a Linguist's Record. Sound Learning in the first two years. Evanston, Ill: Northwestern University Press. 1947.

[2] R. Jakobson. Child Language, Aphasia, and Phonological Universals. The Hague: Moulton. Translation by R. Keller of the original German version of 1941. 1941/1968.

[3] M. Templin. Certain Language Skills in Children: their Development and interrelationships (Monograph Series No. 26) Minneapolis: University of Minnesota Press: Minneapolis 1957.

[4] L. Menn. Phonotactic Rules in Beginning Speech. Language, 7, pp. 41-74. 1971.

[5] N. V. Smith. The Acquisition of Phonology: A Case Study. Cambridge: Cambridge University Press. 1973.

[6] D. Ingram. Phonological Rules in Young Children. Journal of Child Language, 1, pp. 49-64. 1974.

[7] D. Ingram. Phonological Patterns in the Speech of Young Children. In Fletcher, P. and Garman, M. (eds) Language Acquisition. Cambridge: Cambridge University Press. Pp. 133-149. 1979. 
[8] A. Carter. The Transformation of Sensory-Motor Morphemes into Words: A Case Study of the development of 'More' and 'Mine'. Journal of Child Language, 2, pp. 233-250. 1975.

[9] C. A. Ferguson, C. B. Farwell. Words and Sounds in Early Language Acquisition. Language, 51, pp. 49-99. 1975.

[10] P. Kiparsky, L. Menn. On the Acquisition of Phonology. In Macnamara, J. (ed). Language Learning and Thought. New York Academic Press. Pp. 47-78. 1977.

[11] E. Gusmann. Studies in Abstract Phonology. Cambridge, MA: MIT Press. 1980.

[12] M. A. Macken, D. Barton. The Acquisition of the Voicing Contrast in English: The Study of Voice onset time in Eord-Initial Stop Consonants. Journal of Child Language, 7, pp. 41-74. 1980.

[13] L. Menn. Phonological Theory and Child Phonology. In Yeni-Komshian, et al, pp. 23-41. 1980.

[14] L. Menn. Development of Articulatory, Phonetic, and Phonological capabilities. In B. Butterworth (ed). Language Production, Vol. 2. New York: Academic Press, pp. 3-50. 1983.

[15] R. Schwartz, L. Leonard. Do Children Pick and Choose? An Examination of Phonological Selection and Avoidance in Early Acquisition. Journal of Child Language, 9, pp. 319-336. 1982.

[16] K. S. MacKain. Assessing the Role of Experience in Infants' Speech Discrimination. Journal of Child Language, 7, pp. 527-542. 1982.

[17] M. Atlinson. Explanation in the Study of Language Acquisition. Cambridge: Cambridge University press. 1982.

[18] D. Ingram. On Children's Homonyms. Journal of Child Language, 12, pp. 671-680. 1985.

[19] D. Ingram. Jakobson Revisited: Some Evidence from the Acquisition of Polish Phonology. Lingua, 75, pp. 55-82. 1988.

[20] D. Ingram. Phonological Development: Production. In Fletcher, P. and Garman, M. (eds), Language Acquisition, $\left(2^{\text {nd }}\right.$ ed.) Cambridge: Cambridge University Press, pp. 174-197. 1990.

[21] C. Pye, D. Ingram, H. List. A Comparison of Initial Consonant Acquisition in English and Quiche. In K. E. Nelson and Van Kleeck (eds), Children's Language, Vol. 6, pp. 175-190, Hilsdale, NJ: Eelbraum. 1987.

[22] N. B. Ratner. Phonological Analysis of Child Speech. In Sokolov, J. L. and Snow, C. E. (eds). Handbook of Research in Language Development Using CHILDES, pp. 324-334. 1994.

[23] C. LIeo, M. Prinze. Consonant Clusters in Child Phonology and the Directionality of Syllable Assignment.

[24] Journal of Child Language 23, pp 31-56. 1996.

[25] C. Levelt, N. Schiller and W. Levelt. The acquisition of Syllable Types. Language Acquisition 8 (3), pp. 237-264. 2000.
[26] M. H. Keshavarz. And D. Ingram. Phonological Development of a Bilingual Child during Early Meaningful Speech Period. International Journal of Humanities, 8, pp. 1-12. 2002.

[27] J. Stites, K. Demuth and C. Kirk. Markedness Vs. Frequency Effects in Coda Acquisition. Proceedings of $28^{\text {th }}$ Annual Boston University Conference on Language Development 2, pp. 565-576. 2003.

[28] J. Pater, J. Barlow. Consonant Cluster Reduction. Journal of Child Language 30, pp. 487-526. 2003.

[29] C. Kirk, K. Demuth. Asymmetries in the Acquisition of Word-Initial and Word-Final Consonant Clusters. Child Language 32, pp. 709-734. 2005.

[30] M. K. Omar. The Acquisition of Egyptian Arabic as a Native Language. Georgetown University Press: Washington DC. Berkely. 1973.

[31] F. Badri. Acquisition of Lexical Developmental Rules in Moroccan Arabic: Implication for the Development of SA as a Second Language through Literacy. PhD Dissertation, UC. 1983.

[32] M. Al-Amayreh. A Normative Study of the Acquisition of Consonant Sounds in Arabic. PhD Dissertation, University of Florida. 1994.

[33] H. A. Daana. The Development of Consonant Clusters, Stress and Plural Nouns in Jordanian Arabic Child Language. PhD Dissertation. University of Essex: UK. 2009.

[34] J. Salim, M. Mehawesh. Stages in Language Acquisition: A Case Study. English Language and Literature Studies Vol. 4, No. 4 pp. 16-24. 2014.

[35] D. Ingram. First Language Acquisition: Method, Description and Explanation. Cambridge: Cambridge University Press. 1996.

[36] A. J. Elliot. Child Language. Cambridge: Cambridge University Press. 1989.

[37] D. Brown. Principles of Language Learning and Teaching. Longman: the UK. 2000.

[38] H. H. Clark, E. V. Clark. Psychology and Language. New York: Harcourt Brace Jovanoich. 1977.

[39] R. Stark. Stages of Development in the First Year of Life.

[40] In I. G. Yeni-Komshian, et al. (eds) Child Phonology: Vol. 1 Production. New York: Academic Press. 1980.

[41] D. Oller. The Emergence of the Sounds of Speech in Infancy. In I. G. Yeni-Komshian, et al. (eds) Child Phonology, Vol. 1 Production. New York: Academic Press. 1980.

[42] A. Cruttenden. Language in Infancy and Childhood. England: Manchester University Press. 1979.

[43] M. H. Keshavarz. A Practical Course of Phonetics and Phonology. Tehran: SMAT Publishers. 1997.

[44] M. Vihman. Phonological Development: The Origin of Language in the Child. Blackwell Publishing Company: UK. 1996.

[45] N. Adnyani, I. Pastika. Phonological Development in the 
Early Speech of an Indonesian-German Bilingual Child. Research in Language 14, 3, pp. 329-350. 2016.
[46] D. Olmsted. Out of the Mouth of Babies. The Hague: Mouton. 1971. 